УДК 636.598.09: 616.995.1

Стародуб С. С., здобувач вищої освіти ступеня доктора філософії

Полтавська державна аграрна академія

\title{
УДОСКОНАЛЕННЯ КОПРООВОСКОПІЧНОЇ ДІАГНОСТИКИ ТРИХОСТРОНГІЛЬОЗУ ГУСЕЙ
}

\author{
Рецензент - доктор ветеринарних наук А. А. Замазій
}

\begin{abstract}
Мета статmі - удосконалити спосіб копроскопічної зажиттєвої діагностики трихостронгільозу гусей.

Методика дослідження. Використано методи зажиттєвої копроскопічної діагностики із застосуванням флотаційних розчинів: загальновідомі (Фюллеборна, Котельникова-Хренова, Маллорі, Мельничука) та удосконалений способи. Проведено визначення показників інтенсивності інвазії у процесі діагностики трихостронгільозу гусей.
\end{abstract}

Результати дослідження. Встановлено, що удосконалений спосіб із використанням комбінованої флотаиійної рідини виявився найбільш ефективним за трихостронгільозу гусей, ніж методи з використанням насиченого розчину иукру (до 54,99\%), з насиченим розчином нітрату амонію (до 51,30\%), з карбамідом (до 23,11\%). Причому час, витрачений на дослідження однієї проби посліду, становить 17 хвилин.

Елементи наукової новизни. Проведено удосконалення та випробування нового методу флотації, який має високі показники діагностичної ефективності за трихостронгільозу гусей.

Практична значущість. Одержані результати дозволяють рекомендувати удосконалений метод для впровадження у виробництво з метою своєчасного та ефективного діагностування трихостронгільозу у птахівництві.

Ключові слова: трихостронгільоз, гуси, зажиттєва діагностика, копроовоскопія, флотація, ефективність.

Стародуб Євгеній Сергійович - здобувач вищої освіти ступеня доктора філософії кафедри паразитології та ветеринарно-санітарної експертизи, Полтавська державна аграрна академія, вул. Сковороди, 1/3, м. Полтава, 36003, Україна, e-mail: starodub7@i.ua, ORCID ID: 0000-0002-7880-8283.

Постановка проблеми. Основою профілактики нематодозних захворювань $є$ профілактичні та лікувальні дегельмінтизації, доцільність проведення яких базується на результатах, переважно, зажиттевої лабораторної діагностики, а саме гельмінтокопроскопічних досліджень тварин. На сьогодні для діагностики гельмінтозів як людей, так і тварин, зокрема птиці, запропонована значна кількість флотаційних і комбінованих методів копроовоскопії. Ці методи грунтуються на використанні розчинів 3 питомою вагою, яка $\epsilon$ вищою, ніж питома вага яєць гельмінтів, що і обумовлює їх спливання на поверхню флотаційної рідини $[4,5,12,13]$.

Успішність зажиттєвої лабораторної діагностики нематодозів травного каналу птиці, зокрема трихостронгільозу, значною мірою обумовлена ефективністю обраного методу, яка залежить від питомої ваги, в' язкості, ступеня кристалізації флотаційного розчину та часу, що забезпечує максимальне спливання яєць певного виду збудника $[2,6,8]$.

Аналіз останніх досліджень і публікацій, у яких започатковано розв'язання даної проблеми. У практиці для діагностики нематодозів травного каналу людей і тварин серед флотаційних способів широкого розповсюдження набули методи Фюллеборна, Котельникова-Хренова та Дарлінга. Вони вважаються достатньо ефективними для більшості нематодозних захворювань, зручні у застосуванні, не потребують коштовного обладнання та специфічних реактивів $[1,9]$. Водночас повідомляють, що такі методи не завжди ефективні при діагностиці окремих інвазій. Іноді одержані дані авторів щодо їх діагностичної ефективності є суперечливими. Також одні вчені вважають, що розчини окремих солей зі збільшенням їх щільності підвищують флотаційну здатність яєць гельмінтів, інші ж, навпаки, доводять, що це сприяє затримці флотації яєць [10, 11].

Відомо, що у птиці є специфічні збудники нематодозів травного каналу птиці, яйця яких мають характерну будову, а також певну питому вагу, що може впливати на діагностичну ефективність загальновідомих методів копроовоскопії. Згідно з дослідженнями науковців, діагностуючи аскаридіоз 


\section{ВЕТЕРИНАРНА МЕДИЦИНА}

та гетеракоз курей недоліком методу Фюллеборна $\epsilon$ те, що флотація яєць відбувається тривалий час (40-60 хв) і метод $є$ недостатньо ефективним. Недоліком методу Котельникова-Хренова $є$ значний обсяг флотаційної рідини (50-100 мл) і затраченого часу (10 хв) на одне дослідження. Водночас недоліками методу Дарлінга є значна витрата часу на його проведення, i метод виявився недостатньо ефективним за нематодозів курей. Тому автор запропонував удосконалений спосіб діагностики паразитозів птиці, у якому як флотаційну рідину використано суміш аміачної селітри та гліцерину. Причому ефективність запропонованого автором способу виявилася вищою на $26 \%$ порівняно із загальновідомими методами при діагностиці гетеракозу та аскаридіозу курей [7].

Іншими авторами для зажиттєвої діагностики капіляріозу курей запропоновано удосконалений спосіб, який грунтується на застосуванні флотаційного розчину на основі комбінованого розчину цукру та натрію хлориду. Доведено, що запропонований спосіб має вищу діагностичну ефективність за капіляріозу курей порівняно із відомими методами: Фюллеборна (на 21,5-47,4 \%, p<0,001), Котельникова-Хренова $\quad(14,7-15,5 \%, \quad \mathrm{p}<0,05 \ldots$ $\mathrm{p}<0,001)$, Маллорі $(5,4-9,9 \%, \mathrm{p}<0,05)$ та способу із використанням карбаміду $(3,0-6,3 \%, \mathrm{p}<0,01)$ [3].

У зв'язку з цим, метою роботи було удосконалити спосіб копроскопічної зажиттєвої діагностики трихостронгільозу гусей.

У завдання досліджень входило випробувати запропоновану комбіновану флотаційну рідину для діагностики трихостронгільозу гусей; визначити діагностичну ефективність удосконаленого способу та загальновідомих методів флотації при виявленні яєць Trichostrongylus tenuis.

Матеріали і методи досліджень. Дослідження проводилися упродовж 2018 р. на базі лабораторії кафедри паразитології та ветеринарно-санітарної експертизи Полтавської державної аграрної академії.

Для визначення діагностичної ефективності загальновідомих та запропонованого способу копроовоскопічної діагностики трихостронгільозу гусей проведено дослідження хворих гусей, які належали неблагополучним щодо інвазії приватним господарствам Полтавської області. Виявляли інтенсивність інвазії за методом В. Н. Трача, розраховували кількість яєць гельмінтів у 1 г посліду (ЯГП). Порівнювали наступні методи: КотельниковаХренова - 3 аміачною селітрою; Маллорі - 3 насиченим розчином цукру; Мельничука та ін. - 3 карбамідом, а також удосконалений спосіб - 3 використанням комбінованої флотаційної рідини. До- слідження проводили за експозицій 5, 10, 15 та 20 хв. Усього проведено 320 копроовоскопічних досліджень.

Статистичну обробку результатів експериментальних досліджень проводили визначенням середнього арифметичного (M), його похибки (m) та рівня вірогідності (p) з використанням таблиці tкритеріїв Стьюдента.

Результати досліджень. Проведеними дослідженнями встановлено, що за різних експозицій проб найбільшу кількість яєць T. tenuis за показником інтенсивності інвазії виявляли у процесі використання удосконаленого способу (табл. 1).

За експозиції 5 хв. інтенсивність інвазії у процесі використання удосконаленого способу була вищою на $35,38 \%(\mathrm{p}<0,05)$ порівняно із методом Котельникова-Хренова $\quad(33,33 \pm 3,76$ ЯГП), на $33,07 \%(\mathrm{p}<0,05)$ - iз методом Маллорі $(34,55 \pm$ 4,74 ЯГП) та на 9,52 \% - із методом Мельничука (46,67士5,36 ЯГП). За експозиції 10 хв удосконалений спосіб перевищував на 51,30\%, 54,99\% $(\mathrm{p}<0,001)$ та 23,11\% $(\mathrm{p}<0,05)$ ефективність загальновідомих методів (Котельникова-Хренова, Маллорі та Мельничука) у процесі проведення діагностики трихостронгільозу гусей. При дослідженні проб з експозицією 15 та 20 хв. діагностична ефективність удосконаленого способу виявилася вищою на $5,31-24,98 \% \quad(90,50 \pm 9,16-113,00 \pm$ 10,79 ЯГП), ніж загальновідомі методи

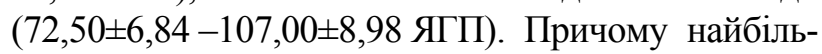
ше спливання яєць нематод виявлено за експозиції

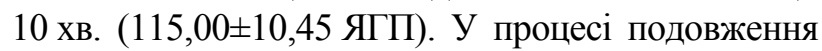
часу відстоювання проб інтенсивність інвазії знижується i становить за експозиції 15 хв. $113,00 \pm 10,79$ ЯГП, за експозиції 20 хв. -

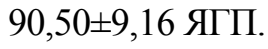

3 метою підтвердження ефективності запропонованого способу зажиттєвої діагностики трихостронгільозу гусей за показниками ергономічності проведено порівняння витраченого часу на одне дослідження порівняно із загальновідомим методом Котельникова-Хренова (прототип) (табл. 2).

Установлено, що за використання методу Котельникова-Хренова, в середньому, витрачено: на підготовку однієї проби посліду $-18,35 \pm 0,10$ хв., на одне діагностичне дослідження - 23,29 $\pm 0,16$ хв. За використання удосконаленого способу одержані показники вказують на високу ефективність цього способу. На підготовку однієї проби витрачено $12,32 \pm 0,09$ хв., що у 1,5 рази $(\mathrm{p}<0,001)$ менше, ніж при використанні прототипу. Водночас на одне діагностичне дослідження витрачено 17,06 $\pm 0,05$ хв., що у 1,4 рази $(\mathrm{p}<0,001)$ швидше порівняно із витратами часу за методом прототипу. 
ВЕТЕРИНАРНА МЕДИЦИНА

\section{1. Діагностична ефективність методів копроовоскопічної діагностики трихостронгільозу гусей $(n=20)$}

\begin{tabular}{|l|c|c|c|c|}
\hline \multirow{2}{*}{ Спосіб } & \multicolumn{4}{|c|}{ Інтенсивність інвазії, ЯГП (М $\pm \mathrm{m})$} \\
\cline { 2 - 5 } & \multicolumn{4}{|c|}{ експозиція, хв } \\
\cline { 2 - 5 } & 5 & 10 & 15 & 20 \\
\hline Удосконалений & $51,58 \pm 6,36$ & $115,00 \pm 10,45$ & $113,00 \pm 10,79$ & $90,50 \pm 9,16$ \\
\hline Котельникова-Хренова & $33,33 \pm 3,76^{*}$ & $56,00 \pm 8,99^{* * *}$ & $86,67 \pm 9,97$ & $67,89 \pm 8,94$ \\
\hline Маллорі & $34,55 \pm 4,74^{*}$ & $51,76 \pm 7,29^{* * *}$ & $90,53 \pm 6,73$ & $72,50 \pm 6,84$ \\
\hline Мельничука та ін. & $46,67 \pm 5,36$ & $88,42 \pm 6,72^{*}$ & $107,00 \pm 8,98$ & $78,50 \pm 7,82$ \\
\hline
\end{tabular}

Примітка: * - $<0,05, * * *-\mathrm{p}<0,001$ - порівняно з показниками за використання удосконаленого способу.

Джерело: власні дослідження.

\section{2. Порівняльна ефективність способів копроовоскопічної діагностики} трихостронгільозу гусей $(n=20)$

\begin{tabular}{|l|c|c|}
\hline \multirow{2}{*}{ Спосіб } & \multicolumn{2}{|c|}{ Показники часу, хв (М $\pm \mathrm{m})$} \\
\cline { 2 - 3 } & підготовки проби & $\begin{array}{c}\text { проведення одного } \\
\text { дослідження }\end{array}$ \\
\hline Котельникова-Хренова (прототип) & $18,35 \pm 0,10$ & $23,29 \pm 0,16$ \\
\hline Удосконалений & $12,32 \pm 0,09^{* * *}$ & $17,06 \pm 0,05^{* * *}$ \\
\hline
\end{tabular}

Примітка: *** - p $<0,001$ - порівняно з показниками за використання способу прототипу.

Джерело: власні дослідження.

\section{Висновки:}

1. Встановлено, що удосконалений спосіб зажиттєвої копроовоскопічної діагностики трихостронгільозу гусей перевищує ефективність методу Котельникова-Хренова на $21,5-47,4 \%$ $(\mathrm{p}<0,001)$, Маллорі - на 3,0-6,3\% $(\mathrm{p}<0,01)$ та Мельничука - на 3,0-6,3\% $(\mathrm{p}<0,01)$.

\section{БІБЛІОГРАФІЯ}

1. Богач М. В., Березовський А. В., Тараненко І. Л. Інвазійні хвороби свійської птиці. Київ : Ветінформ, 2007. 224 с.

2. Дахно І. С., Дахно Ю. І. Екологічна гельмінтологія. Суми, 2010. 220 с.

3. Свстаф'єва В. О., Натягла І. В., Мельничук $B$. B. Порівняльна ефективність зажиттєвих способів копроовоскопічної діагностики капіляріозу курей. Вісник Сумського наџіонального аграрного університету. 2016. Вип. 11 (39). C. $150-154$.

4. Котельников Г. А. Диагностика гельминтозов животных. Москва : Колос, 1974. 240 с.

5. Котельников Г. А. Рекомендации по диагностике гельминтозов сельскохозяйственных животных. Москва : Россельхозиздат, 1981. 31 с.

6. Котельников Г. А. Гельминтологические исследования животных и окружающей среды. Москва : Колос, 1984. 208 с.

7. Крайнов В. В., Лутфуллин М.Х., Лутфуллина $H$. А. Копрологическая диагностика кишеч-
2. Запропонований спосіб є ергономічним, оскільки час на дослідження однієї проби посліду становить 17 хвилин.

Перспективи подальшої роботи в цьому напрямі. Перспективами подальших досліджень $\epsilon$ визначення ефективності сучасних лікарських засобів за трихостронгільозу гусей.

ных нематодозов кур. Ученые записки Казанской государственной академии ветеринарной медичины им. Н. Э Баумана. 2012. Т. 211. С. 79-81.

8. Лутфуллин М. Х., Латыпов Д. Г., Корнишина М. Д. Гельминтокопроскопические исследования животных. Казань, 2002. 24 с.

9. Лутфуллин М. Х., Папуниди К. Х., В Волков А. Х., Латыпов Д. Г. Лабораторное исследование кала у животных. Казань, 2015. С. 10-18.

10. Comparison of three copromicroscopic methods to assess albendazole efficacy against soiltransmitted helminth infections in school-aged children on Pemba Island / M. Albonico et al. Transactions of the Royal Society of Tropical Medicine and Hygiene. 2013. № 107 (8). P. 493-501.

11. Habtamu K., Degarege A., Ye-Ebiyo Y., Erko B. Comparison of the Kato-Katz and FLOTAC techniques for the diagnosis of soil-transmitted helminth infections. Parasitology International. 2011 № 60 (4). P. 398-402.

12. Mini-FLOTAC and Kato-Katz: helminth 


\section{ВЕТЕРИНАРНА МЕДИЦИНА}

eggs watching on the shore of Lake Victoria / B. Barda et al. Parasites and Vectors. 2013. № 6 (1). P. 220.

13. The Mini-FLOTAC technique for the

\section{REFERENCES}

1. Bogach, M. V., Berezovskij, A. V., \& Taranenko, I. L. (2007). Invazijni hvorobi svijs'koï ptici [Invasive diseases of poultry]. Kyiv: Vetinform [In Russian].

2. Dahno, I. S., \& Dahno, Ju. I. (2010). Ekologichna gel'mintologija [Ecological Helminthology]. Sumy [In Ukrainian].

3. Yevstafieva, V. O., Natjagla, I. V., \& Melnychuk, V. V. (2016). Porivnjal'na efektyvnist' zazhyttjevyh sposobiv koproovoskopichnoi' diagnostyky kapiljariozu kurej [Comparative efficiency of life-time methods of coproscopic diagnostics of capillary of chickens]. Visnyk Sums'kogo nacional'nogo agrarnogo universytetu, 11 (39), pp. 150-154 [In Ukrainian].

4. Kotelnikov, G. A. (1974). Diagnostika gel'mintozov zhivotnyh [Diagnosis of animal helminths]. Moskva: Kolos [In Russian].

5. Kotelnikov, G. A. (1981). Rekomendacii po diagnostike gel'mintozov sel'skohozjajstvennyh zhivotnyh [Recommendations for the diagnosis of helminthiasis in farm animals]. Moskva: Rossel'hozizdat [In Russian].

6. Kotelnikov, G. A. (1984). Gel'mintologicheskie issledovanija zhivotnyh $i$ okruzhajushhej sredy [Helminthological studies of animals and the environment]. Moskva: Kolos [In Russian].

7. Krajnov, V. V., Lutfullin, M. H., \& Lutfullina, N. A. (2012). Kaprologicheskaja diagnostika kishechnyh nematodozov kur [Coprologic diagnosis of intestinal nematodes of chickens]. Uchenye zapiski Kazanskoj gosudarstvennoj akademii veterinarnoj mediciny im. N. Je Baumana, 211, pp. 79-81 [In Russian]. diagnosis of helminth and protozoan infections in humans and animals / Cringoli G. et al. Nature Protocols. 2017. № 12 (9). P. 1723-1732.

8. Lutfullin, M. H., Latypov, D. G., \& Kornishina, M. D. (2002). Gel'mintokoproskopicheskie issledovanija zhivotnyh [Helminthocomposcopic studies of animals]. Kazan' [In Russian].

9. Lutfullin, M. H., Papunidi, K. H., Volkov, A. H., \& Latypov, D. G. (2015). Laboratornoe issledovanie kala u zhivotnyh [Laboratory study of animals' feces]. Kazan' [In Russian].

10. Albonico, M., Rinaldi, L., Sciascia, S., Morgoglione, M. E., Piemonte, M., Maurelli, M. P., Musella, V., Utzinger, J., Ali, S. M., Ame, S. M., \& Cringoli, G. (2013). Comparison of three copromicroscopic methods to assess albendazole efficacy against soil-transmitted helminth infections in school-aged children on Pemba Island. Transactions of the Royal Society of Tropical Medicine and Hygiene, 107 (8),pp. 493-501 [In English].

11. Habtamu, K., Degarege, A., Ye-Ebiyo, Y., \& Erko, B. (2011). Comparison of the Kato-Katz and FLOTAC techniques for the diagnosis of soiltransmitted helminth infections. Parasitology International, 60 (4), pp. 398-402 [In English].

12. Barda, B., Zepherine, H., Rinaldi, L., Cringoli, G., Burioni, R., Clementi, M., \& Albonico, M. (2013). Mini-FLOTAC and KatoKatz: helminth eggs watching on the shore of Lake Victoria. Parasites and Vectors, 6(1), pp. 220 [In English].

13. Cringoli, G., Maurelli, M. P., Levecke, B., Bosco, A., Vercruysse, J., Utzinger, J., \& Rinaldi, L. (2017). The Mini-FLOTAC technique for the diagnosis of helminth and protozoan infections in humans and animals. Nature Protocols, 12 (9), pp. 1723-1732 [In English].

\section{Стародуб Е. С. Совершенствование копроовоскопической диагностики трихостронгилеза гусей}

Цель статьи - усовершенствовать способ копроскопической прижизненной диагностики трихостронгилеза гусей.

Методика исследования. Использованы методы прижсизенной копроскопической диагностики с применением флотационных растворов: общеизвестные (Фюллеборна, Котельникова-Хренова, Маллори, Мельничука) и усовершенствованный способы. Проведено определение показателей интенсивности инвазии в процессе диагностики трихостронгилеза гусей.

Результаты исследования. Установлено, что усовериенствованный способ с использованием комбинированной флотаџионной жидкости оказался наиболее эффективньм при трихостронгилезе гусей, чем методы с использованием насыщенного раствора сахара (до 54,99\%), с насыщенным рас- 


\section{ВЕТЕРИНАРНА МЕДИЦИНА}

твором нитрата аммония (до 51,30\%), с карбамидом (до 23,11\%). Причем время, затраченное на исследование одной пробы помета, составляет 17 минут.

Элементы научной новизны. Проведено усовершенствование и испытание нового метода флотации, который имеет высокие показатели диагностической эффективности при трихостронгилезе гусей.

Практическая значимость. Полученные результаты позволяют рекомендовать усовершенствованный метод для внедрения в производство с ичелью своевременного и эффективного диагностирования трихостронгилеза в птицеводстве.

Ключевые слова: трихостронгилез, гуси, прижизненная диагностика, копроскопия, флотация, эффективность.

Стародуб Евгений Сергеевич - соискатель высшего образования степени доктора философии кафедры паразитологии и ветеринарно-санитарной экспертизы, Полтавская государственная аграрная академия, ул. Сковороды, 1/3, г. Полтава, 36003, Украина, e-mail: starodub7@i.ua, ORCID ID: 00000002-7880-8283.

\section{Starodub Ye. S. Improving coproovoscopic diagnostics of trichostrongylosis of geese}

The purpose of the article is to improve the method of coproovoscopic lifetime diagnostics of geese trichostrongylosis.

Methods of research. Commonly known methods of lifetime coproscopic diagnostics (of Fülleborn, Kotelnykova-Khrenova, Mallory, Melnychuka) using flotation solutions were used, and also the methods were improved. The determining of the invasion intensity indices in the process of diagnosing geese trichostrongylosis was carried out.

The research results. It has been established that the improved method with the use of combined flotation fluid was proved to be the most effective in diagnosing trichostrongylosis of geese than methods with the use of saturated sugar solution (up to 54.99\%), with a saturated solution of ammonium nitrate (up to $51.30 \%$ ), with urea (up to 23,11\%). Moreover, the time taken to study one sample of the litter is 17 minutes.

The elements of scientific novelty. The improving and testing of a new flotation method, which has high indicators of diagnostic effectiveness for geese trichostrongylosis have been carried out.

Practical significance. The obtained results allow us to recommend the improved method for introduction in production in order to timely and effectively diagnose trichostrongylosis in poultry farming.

Key words: trichostrongylosis, geese, lifetime diagnostics, coproscopy, flotation, effectiveness.

Starodub Yevhenii Serhiiovych - Ph.D. degree applicant of higher education of the Department of Parasitology and Veterinary-Sanitary Expert Examination, Poltava State Agrarian Academy, 1/3, Skovorody str., Poltava, 36003, Ukraine, e-mail: starodub7@i.ua, ORCID ID: 0000-0002-7880-8283.

Стаття надійшла до редакції 13.02.2019 р.

Бібліографічний опис для цитування :

Стародуб $C$. С. Удосконалення копроовоскопічної діагностики трихостронгільозу гусей. Вісник ПДАА. 2019. № 1. С. 222-226.

DOI 10.31210/visnyk2019.01.26

(c) Стародуб Свгеній Сергійович, 2019 